\title{
Meiofauna distribution in a mangrove forest exposed to shrimp farm effluents (New Caledonia)
}

\author{
Della Patrona Luc ${ }^{1}$, Marchand C. ${ }^{2,{ }^{*}}$, Hubas C. ${ }^{3}$, Molnar N. ${ }^{2,3}$, Deborde J. $^{2}$, Meziane T. ${ }^{3}$
}

1 Départment of Lagons, Ecosystems and Sustainable Aquaculture (LEAD/NC), Ifremer, 101, Promenade Roger Laroque, Centre IRD, BP 2059-98846, Nouméa Cedex, New Caledonia, France

2 IRD, UR 206, UMR 7590-IMPMC, F-98848, New Caledonia, France

${ }^{3}$ Muséum National d'Histoire Naturelle, UMR BOREA, Sorbonne Universités, UPMC Univ Paris 6, CNRS 7208, IRD 207, UCBN, UA, CP 53, 61 rue Buffon, 75231, Paris Cedex 5, France

* Corresponding author : C. Marchand, email address : cyril.marchand@ird.fr

\begin{abstract}
:
Meiofauna abundance, biomass and individual size were studied in mangrove sediments subjected to shrimp farm effluents in New Caledonia. Two strategies were developed: i) meiofauna examination during the active (AP) and the non-active (NAP) periods of the farm in five mangrove stands characteristics of the mangrove zonation along this coastline, ii) meiofauna examination every two months during one year in the stand the closest to the pond (i.e. Avicennia marina). Thirteen taxonomic groups of meiofauna were identified, with nematodes and copepods being the most abundant ones. Meiofauna abundance and biomass increased from the land side to the sea side of the mangrove probably as a result of the increased length of tidal immersion. Abundance of total meiofauna was not significantly different before and after the rearing period. However, the effluent-receiving mangrove presented twice the meiofauna abundance and biomass than the control one. Among rare taxa, mites appeared extremely sensitive to this perturbation.
\end{abstract}

\section{Highlights}

13 taxonomic groups of meiofauna were identified in mangrove sediments. Meiofauna abundance and biomass increased from the land side to the sea side. Meiofauna distribution was controlled by the mangrove zonation. Short term effect of aquaculture effluents on meiofauna distribution were not evidenced. Long term effects were higher meiofaunal diversity, abundance and biomass.

Keywords : Mangrove, Meiofauna, Shrimp farming, Environmental status, New Caledonia 


\section{Introduction}

In New Caledonia, shrimp ponds cover 680 ha, producing $\sim 2,000$ metric tons of shrimps per year (Della Patrona and Brun, 2009). In contrast to other parts of the world, farms are built on salt flats, developing upstream the mangrove forests, and there were no direct losses of mangroves due to pond construction. However, pond effluents are discharged into the adjacent mangroves, considered to be a "natural biofilter" that can reduce or eliminate impacts on the surrounding World Heritage listed lagoon and coral reef (Thomas et al., 2010; Molnar et al., 2013). The impact and fate of shrimp farm effluents in mangrove ecosystems can be studied using physico-chemical parameters, nutrients concentration, quantity and quality of organic matter. (McKinnon et al., 2002; Costanzo et al., 2004; Lacerda et al., 2006; Mirto et al., 2007; Pusceddu et al., 2008). Benthic organisms, which are sensitive to physical, chemical and biological disturbances, can also act as relevant ecological indicators of the status of the receiving ecosystem (Lamparadariou et al., 2005). Actually, benthic trophic status based on organic matter variables is not sufficient to provide a sound assessment of the environmental quality of the ecosystem, which can be obtained combined with a study on meiofaunal variables (Bianchelli et al., 2016). Meiofauna has been used as ecological descriptors in numerous studies dealing with the impact of fish farms (Vezzulli et al., 2008; Grego et al., 2009; Mirto et al, 2010; 2012, 2014; Bianchelli et al., 2016) and to a lesser extent of mussel farms (Mirto et al ., 2000; Danavoro et al., 2004), oyster farms (Castel et al., 1989; Dinet et al., 1990), and algae farms (Olafsson et al., 1995). The general outcome from the literature is that aquaculture farms biodeposition typically alter meiofaunal abundance, diversity, biomass and species composition. The disappearance of the rare taxa, representing $<1 \%$ of the total meiofauna abundance, were usually also described under fish farm influence (Mirto et al., 2010).

To understand the putative impact on effluents on meiofauna variables in mangrove, one has also to understand the natural distribution of meiofauna in this specific ecosystem. However, few references were interested in meiofauna distribution along a tidal gradient under semi-arid climate (Debenay et al., 2015). Environmental cues such as temperature, salinity, length of tidal immersion, redox conditions and sediment grain size are the most important factors regulating the zonation patterns of meiofauna in mangrove estuaries (Alongi, 1987a,b; Anzari et al., 1993; Thilagavathi et al., 2011). 
These parameters can vary according to the mangrove stand (Vanhove et al., 1992; Marchand et al., 2004; Chinnadurai and Fernando, 2007) and its position in the tidal zone that induces difference in waterlogging, leading notably to different pore water salinity (Marchand et al., 2011).

In the mangrove studied herein, the influence of the effluents on $\mathrm{C}, \mathrm{N}$, and P dynamic as well as on the physico-chemical characteristics of the sediment were already demonstrated (Molnar et al., 2013; 2015; Aschenbroich et al., 2015). Organic matter exported from shrimp farm stimulated oxygen demand and nutrient regeneration rates. However, the major role of mangrove sediments was to process the effluent PON loads and to export them directly in dissolved forms to the surrounding lagoon waters, or indirectly by stimulating bacterial and phytoplankton biomass production. No sign of saturation, eutrophication or anoxia of the effluent receiving mangrove was observed. Thus, we suggested that the mangrove was only a partial filter for the shrimp farm effluent. In the specific context, our first hypothesis is that the abundance, biomass and composition of meiofauna collected in the effluents receiving mangrove were not severely affected by shrimp farm effluents. Our second hypothesis is that the distribution, abundance, individual weight and biomass of meiofauna taxa will differ between mangrove stands as a result of their specific physico-chemical properties.

Our objectives were thus: i) to assess the influence of shrimp farming effluents on meiofauna distribution, ii) to determine the influence of the mangrove stand on this distribution. To reach our goals, we developed two sampling strategies: i) collection of surface sediments during the active (AP) and non-active periods (NAP) of the farm in the different mangrove stands characteristic of zonation under semi-arid climate, ii) a one-year survey of the meiobenthos distribution in a stand where the effluents are released (i.e. Avicennia marina) compared to a control one. Abundance and biomass of meiobenthos were measured, as well as the Chl-a content of surface sediments. To our knowledge, this study is the first one using meiofauna as ecological indicators in mangrove sediments receiving shrimp farm effluents. 


\section{Material and methods}

\subsection{Study site and sampling strategy}

The work was carried out in two mangroves of similar size located in Saint Vincent Bay (Boulouparis, New Caledonia) that display the same mangrove zonation: i) at the back edge of the mangrove swamp, the area is characterized by salt flats, a highly saline zone submerged only at high spring tides and covered sparsely in the most downstream stretches with Sarcocornia quinqueflora and Suadea australis bushes; ii) a second stand of vegetation, downstream, is characterized by the presence of Avicennia marina; iii) finally, the seaward edge is characterized by Rhizophora stylosatrees, which are always submerged at high tide.

The control mangrove area $\left(21^{\circ} 54^{\prime} \mathrm{S}, 166^{\circ} 04^{\prime} \mathrm{E}\right)$ covered 22 ha (Figure 1) is free from any aquaculture or agriculture influences. The effluent-receiving mangrove $\left(21^{\circ} 56^{\prime} \mathrm{S}, 166^{\circ} 04^{\prime} \mathrm{E}\right.$; of total area 28 ha, located $2 \mathrm{~km}$ from the control mangrove) receives effluent discharges from the 2 ponds ( $\mathrm{K}$ and $\mathrm{L}$ ) of the "Ferme Aquacole de la Ouenghi" shrimp farm (FAO).

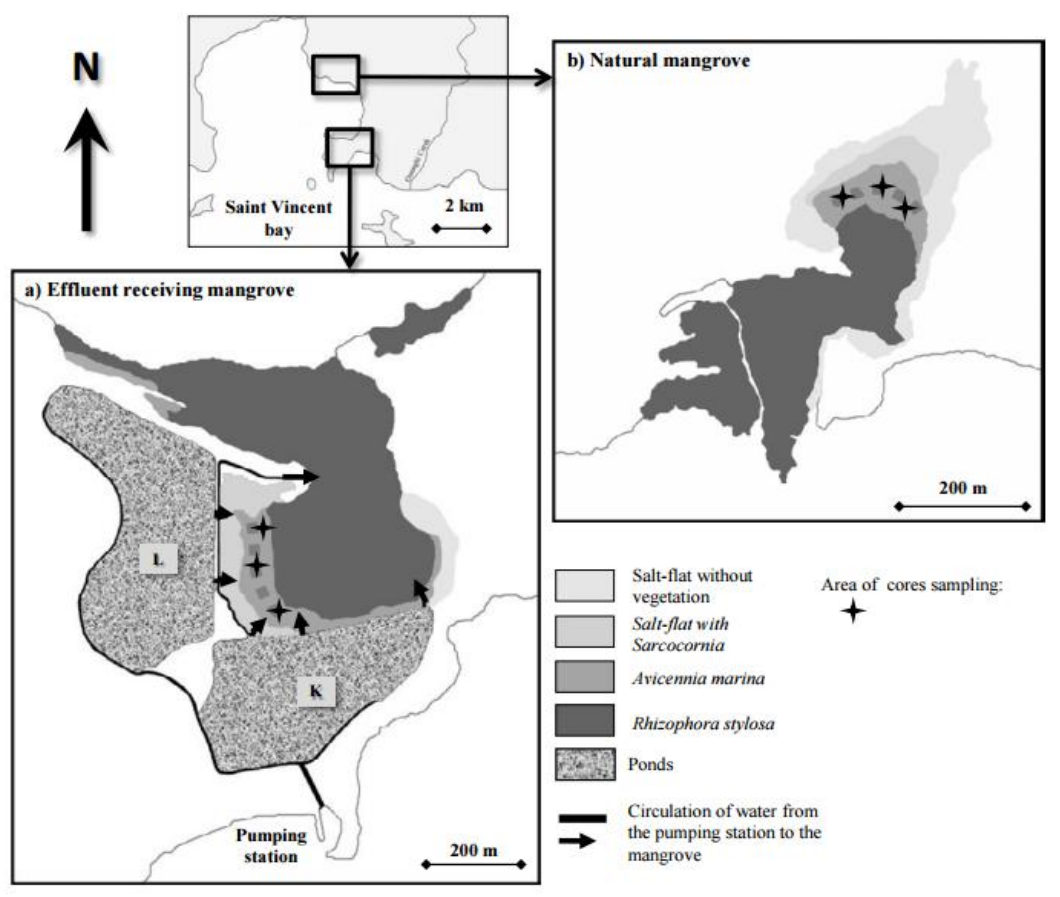

94 Figure 1 Map showing: i) the location of the effluent receiving (a) and control mangrove (b) in 95 Saint Vincent Bay (New Caledonia); ii) the effluent outlets: at the west and east side of the K and 96 L numbered Ponds (exposed site); iii) the locations of sampling sites $\mathbf{b}$ are symbolized by crosses. 
Like the majority of shrimp farms in New Caledonia, FAO operates a semi-intensive rearing system. Ponds were stocked with blue shrimp, Litopenaeus stylirostris, at an abundance of $\sim 17$ ind. $\mathrm{m}^{-2}$ in December 2008 , and reared for $\sim 8$ months. The shrimp were fed with locally produced feed pellets (35-40\% protein), which were added daily throughout the rearing period, with inputs increasing from $\sim 0.25$ to $\sim 3.5 \mathrm{~kg} \cdot \mathrm{ha}^{-1} \cdot \mathrm{d}^{-1}$ over the rearing cycle as the shrimps grew. The volume of water discharged into the mangrove corresponded to the volume of the daily water renewed, and increased progressively with the growth of postlarvae and adult organisms from 0 to about $20 \%$ of the volume of the pond per day. The ponds were drained in July 2009 after the last shrimp harvest and allowed to dry for a period of about three to four months prior to the start of the next breeding cycle.

The effect of shrimp effleunts on mangrove meiofauna was investigated by means of two complementary approaches: dual-season spatial studies in the whole effluent-receiving mangrove and one-year monitoring in the Avicennia stand both in control and effluent receiving mangroves.

110 The spatial studies were carried out in the mangrove areas adjacent to FAO during two distinct periods of farm activity: the non-active period (NAP, November 2009) one month before the beginning of rearing, and the active period (AP, June 2010) characteristic of breeding running at full load.

113 Forty-five geo-referenced samples were collected throughout the whole mangrove area, subdivided in 14 accordance with the objective of the study into five vegetation zones=stands in relation to their different immersion time, roots systems and suspected effluent plume effect: $\mathrm{n}^{\circ} 1$ salt flat " $\mathrm{S}$ ", $\mathrm{n}^{\circ} 2 \mathrm{~A}$. 116 marina "A", $\mathrm{n}^{\circ} 3$ mixed zone harboring A. marina and Rhizophora stylosa "MAR", $\mathrm{n}^{\circ} 4$ central zone 117 with $R$. stylosa “CR", and n5 seaward edge with $R$. stylosa "ER".

118 Sediment samples were collected in triplicate for meiofaunal analysis by means of Plexiglas cores 119 (inner diameter $3.6 \mathrm{~cm}$, corresponding to $\sim 10.7 \mathrm{~cm}^{2}$ surface area) to a depth of $2 \mathrm{~cm}$. Sediment 120 samples were immediately fixed with buffered $4 \%$ formaldehyde solution until laboratory analyses 121 and stained with a few drops of Rose Bengal $\left(0.5\right.$ g. $\left.1^{-1}\right)$.

122 In both Avicennia stands (control and effluent-receiving), eight sampling campaigns were conducted 123 from February 2009 to February 2010. Sampling campaigns were conducted to cover the entire 124 production cycle of the farm, with four campaigns during the rearing period, and four during the 
"drying" period. Five sub-areas were defined for each Avicennia stand (effluent-receiving and control), and five replicates were collected in each sub-area. One replicate was obtained by pooling 5 sub-samples.

\subsection{Analytical methods}

\subsubsection{Meiofauna analysis}

In the laboratory each sample was rinsed and filtered on 1000 and $45 \mu \mathrm{m}$ mesh sieves. The $45 \mu \mathrm{m}$ mesh residue sieve was centrifuged three times in the Ludox HS40 $(\mathrm{d}=1.15)$. The animals were counted on a 200-wells glass plate and identified to major groups through an adequate detailed observation (microscopic ampliation or with a $80 x$ binocular magnifier) according reference manuals (Higgins and Thiel, 1988; Giere, 1993). Meiofaunal biomass was estimated from size measurements of different animals. The length and width of up to 30 organisms per major taxon were measured using a dissecting microscope fitted with a micrometer scale. These measurements were used for further conversion into biomass, using the specific conversion factors for each taxonomic group following Wieser (1960) and Warwick and Price (1979) for nematodes, Warwick and Gee (1984) and Riemann et al. (1990) for copepods, Gradinger et al. (1999) for crustacean nauplii, Ruttner-Kolisko (1977) and Bottrell et al. (1976) for rotifers, and Guo et al. (2005) and Nozais et al. (2005) for the other groups.

\subsubsection{Chlorophyll a analysis}

Chl-a was extracted from freeze-dried sediments using a 93\% methanol solution and their

concentrations were determined fluorometrically (Yentsch and Menzel, 1963). The fluorometer used

was a Turner Designs TD700 equipped with an optical kit ${ }^{\circ} 7000-961$ including an excitation filter of 340-500 nm wavelength, and an emission filter up to $665 \mathrm{~nm}$ wavelength. Pigments in methanol were then excited in the fluorometer with a $450 \mathrm{~nm}$ wavelength beam of light and fluorescence emitted at $664 \mathrm{~nm} . \mathrm{MPB}$ is the microphytobenthic biomass (mg Chl-a.m ${ }^{-2}$ ), converted to autotrophic carbon (mg C. $\mathrm{m}^{-2}$ ) assuming a C:Chl-a ratio of 40:1 (de Jonge, 1980 in Nozais et al., 2005). 


\subsection{Statistical analysis}

Principal component analysis (PCA) was used to analyze: i) the dual season spatial study data, in which observations (meiofauna abundance and biomass) are described by several inter-correlated quantitative dependent variables (i.e. spatial study, vegetation, period), ii) the one-year monitoring in effluent-receiving and controlled A. marina stand data (environmental status effect vs. control, campaign date).

PRIMER 6 software was used for multivariate analysis. Data matrices were used to create triangular similarity matrices, based on the Bray-Curtis similarity coefficient. Differences in meiofauna composition among factors were tested using one-way or two-ways analysis (as appropriate) of similarity (ANOSIM) and the statistical test was computed after 5,000 permutations. No transformation was applied to the data and factors used for analysis. Where differences in meiofauna composition were detected between factors (Status, date), similarity of percentage tests (SIMPER) were used to determine which meiofauna taxa drove the observed differences between the two sets of data. Differences in abundance of meiofauna between sampling times and vegetation stands were tested using analysis of variance. Prior to ANOVA, Chl-a data were $\log (\mathrm{x}+1)$ transformed and all data were tested for homoscedasticity (Bartlett test) and normal distribution (Shapiro-Wilk). Tukey's HSD post-hoc tests were then used to determine differences between groups. Chl-a data were, first, analyzed by a non-parametric Kruskall-Wallis test, and then by a Wilcoxon test to compare mean values for pairs (control mangrove vs. effluent-receiving mangrove, between campaigns). For 171 kinorhynchs and mites data homoscedasticity and normal distribution of residuals condition were not 172 fulfilled. So kinorhynch and mites data were tested using a non-parametric test (Kruskal-Wallis test). 173 Van Der Waerden test was used to convert the ranks from Kruskal-Wallis one-way analysis of 174 variance to quantiles of the standard normal distribution called normal scores and the test was 175 computed from these normal scores. Regression analysis were used to identify relationship between 176 MPB (Microphytobenthos) and total meiofauna biomass. All these tests were performed using the R 177 version 2.9.0 2009 software and for all tests the probability $\alpha$ was set at 0.05 . The initial hypothesis Ho 178 (means of the groups are equal to one another) is rejected if the p-values $<\alpha$ i.e. at least one group is 179 different from the other one. 
1

\section{Results}

\subsection{Dual-season spatial study in the different stands of the effluent-receiving mangrove}

\subsubsection{General characteristics of meiofauna distribution}

Within the surface sediment of the mangrove receiving shrimp farm effluents, a total of 13

185 taxonomic groups of meiofauna was identified during the two spatial studies carried out in November 1862009 and June 2010 (Table 1).

187 Table 1 Mean abundances $\left(\mathrm{Nb} \times \mathbf{1 0} \mathrm{cm}^{-2} \pm\right.$ Standard Deviation) of meiobenthic taxa recorded

seaward edge with $R$. stylosa.

\begin{tabular}{|c|c|c|c|c|c|c|c|c|c|c|c|c|c|c|c|}
\hline \multicolumn{16}{|c|}{ Non Active Period (NAP) } \\
\hline \multirow[t]{2}{*}{ Taxa } & \multicolumn{3}{|c|}{$\mathbf{S}$} & \multicolumn{3}{|c|}{$\bar{A}$} & \multicolumn{3}{|c|}{ MAR } & \multicolumn{3}{|c|}{ CR } & \multicolumn{3}{|c|}{ ER } \\
\hline & Abund. & & S.D & Abund. & & S.D & Abund. & & S.D & Abund. & & S.D & Abund. & & S.D \\
\hline Amphipoda & 0.0 & \pm & 0.0 & 0.0 & \pm & 0.0 & 0.0 & \pm & 0.0 & 0.2 & \pm & 0.8 & 2.3 & \pm & 5.4 \\
\hline Bivalvia & 0.0 & \pm & 0.0 & 0.4 & \pm & 1.0 & 0.4 & \pm & 1.0 & 0.0 & \pm & 0.0 & 2.3 & \pm & 3.1 \\
\hline Copepoda & 17.4 & \pm & 32.6 & 45.3 & \pm & 33.4 & 54.6 & \pm & 66.8 & 52.4 & \pm & 48.2 & 72.3 & \pm & 98.3 \\
\hline Gastropoda & 2.5 & \pm & 5.5 & 0.1 & \pm & 0.3 & 0.0 & \pm & 0.0 & 0.3 & \pm & 0.5 & 2.1 & \pm & 2.1 \\
\hline Halacaroidea & 0.9 & \pm & 1.5 & 0.3 & \pm & 0.7 & 0.6 & \pm & 1.1 & 0.8 & \pm & 1.1 & 1.3 & \pm & 2.0 \\
\hline Kinorhyncha & 0.2 & \pm & 0.5 & 0.6 & \pm & 1.2 & 0.1 & \pm & 0.3 & 0.5 & \pm & 1.9 & 5.1 & \pm & 11.6 \\
\hline Crustacean nauplii & 23.6 & \pm & 37.4 & 4.1 & \pm & 4.7 & 16.9 & \pm & 28.4 & 4.0 & \pm & 9.8 & 19.0 & \pm & 27.5 \\
\hline Nematoda & 584.7 & \pm & 588.7 & 761.7 & \pm & 411.3 & 881.8 & \pm & 697.7 & 932.1 & \pm & 454.8 & 1255.1 & \pm & 414.2 \\
\hline Oligochaeta & 1.3 & \pm & 1.7 & 7.8 & \pm & 18.8 & 1.1 & \pm & 1.7 & 2.3 & \pm & 3.4 & 7.3 & \pm & 5.9 \\
\hline Ostracoda & 1.8 & \pm & 3.9 & 1.1 & \pm & 1.5 & 0.3 & \pm & 0.4 & 0.4 & \pm & 1.5 & 2.1 & \pm & 2.9 \\
\hline Polychaeta & 0.5 & \pm & 0.7 & 5.4 & \pm & 12.4 & 5.9 & \pm & 15.6 & 12.0 & \pm & 17.9 & 51.1 & \pm & 44.8 \\
\hline Rotifera & 1.5 & \pm & 3.3 & 19.1 & \pm & 33.7 & 6.0 & \pm & 13.3 & 0.6 & \pm & 1.4 & 0.3 & \pm & 0.4 \\
\hline Tardigrada & 53.2 & \pm & 116.9 & 0.0 & \pm & 0.0 & 0.0 & \pm & 0.0 & 0.0 & \pm & 0.0 & 0.0 & \pm & 0.0 \\
\hline Turbellarians & 0.0 & \pm & 0.0 & 0.0 & \pm & 0.0 & 0.0 & \pm & 0.0 & 0.0 & \pm & 0.0 & 0.0 & \pm & 0.0 \\
\hline
\end{tabular}

shrimp farm effluents for twenty-five years. "S" salt-marsh, "A" A.marina, "MAR" mixed zone harboring $A$. marina and Rhizophora stylosa, "CR" central zone with $R$. stylosa and "ER" 


\begin{tabular}{|c|c|c|c|c|c|c|c|c|c|c|c|c|c|c|c|}
\hline \multicolumn{16}{|c|}{ Active Period (AP) } \\
\hline \multirow[t]{2}{*}{ Taxa } & \multicolumn{3}{|c|}{$S$} & \multicolumn{3}{|c|}{ A } & \multicolumn{3}{|c|}{ MAR } & \multicolumn{3}{|c|}{ CR } & \multicolumn{3}{|c|}{ ER } \\
\hline & Abund. & & S.D & Abund. & & S.D & Abund. & & S.D & Abund. & & S.D & Abund. & & S.D \\
\hline Amphipoda & 0.0 & \pm & 0.0 & 0.0 & \pm & 0.0 & 0.3 & \pm & 0.9 & 0.0 & \pm & 0.0 & 0.8 & \pm & 1.7 \\
\hline Bivalvia & 0.0 & \pm & 0.0 & 0.0 & \pm & 0.0 & 0.0 & \pm & 0.0 & 0.0 & \pm & 0.0 & 2.6 & \pm & 4.4 \\
\hline Copepoda & 24.3 & \pm & 32.2 & 58.1 & \pm & 36.6 & 44.4 & \pm & 77.3 & 37.7 & \pm & 37.4 & 79.7 & \pm & 41.3 \\
\hline Gastropoda & 0.4 & \pm & 0.6 & 0.4 & \pm & 0.5 & 0.2 & \pm & 0.5 & 0.2 & \pm & 0.5 & 2.7 & \pm & 4.4 \\
\hline Halacaroidea & 1.0 & \pm & 1.7 & 0.8 & \pm & 0.9 & 0.2 & \pm & 0.5 & 0.5 & \pm & 1.2 & 2.9 & \pm & 3.5 \\
\hline Kinorhyncha & 0.0 & \pm & 0.0 & 0.1 & \pm & 0.4 & 0.5 & \pm & 1.3 & 0.1 & \pm & 0.6 & 15.0 & \pm & 23.7 \\
\hline Crustacean nauplii & 101.1 & \pm & 114.0 & 18.6 & \pm & 30.3 & 13.6 & \pm & 25.9 & 0.5 & \pm & 1.0 & 6.3 & \pm & 8.9 \\
\hline Nematoda & 235.0 & \pm & 268.2 & 656.1 & \pm & 565.9 & 535.6 & \pm & 55.8 & 727.7 & \pm & 389.6 & 1798.8 & \pm & 1143.0 \\
\hline Oligochaeta & 0.1 & \pm & 0.3 & 0.7 & \pm & 1.4 & 0.6 & \pm & 1.0 & 1.5 & \pm & 2.4 & 4.5 & \pm & 5.7 \\
\hline Ostracoda & 62.4 & \pm & 130.0 & 10.8 & \pm & 20.6 & 2.9 & \pm & 8.5 & 0.0 & \pm & 0.0 & 6.3 & \pm & 8.3 \\
\hline Polychaeta & 2.0 & \pm & 4.5 & 8.9 & \pm & 12.9 & 1.4 & \pm & 2.5 & 8.1 & \pm & 14.7 & 49.9 & \pm & 36.7 \\
\hline Rotifera & 0.0 & \pm & 0.0 & 2.8 & \pm & 6.8 & 10.4 & \pm & 24.7 & 1.3 & \pm & 4.4 & 8.12 & \pm & 15.6 \\
\hline Tardigrada & 0.7 & \pm & 1.1 & 0.3 & \pm & 0.5 & 0.0 & \pm & 0.0 & 0.0 & \pm & 0.0 & 0.0 & \pm & 0.0 \\
\hline Turbellarians & 0.0 & \pm & 0.0 & 0.0 & \pm & 0.0 & 0.0 & \pm & 0.0 & 0.1 & \pm & 0.3 & 0.1 & \pm & 0.3 \\
\hline
\end{tabular}

196 With regard to meiofauna abundance, PCA “inter" inertia was explained by spatial study (0.8\%), 197 period $(0.8 \%)$ and vegetation $(15.2 \%)$. Both vegetation and period factors represent $22.8 \%$ of total 198 inertia. In terms of biomass, PCA “inter" inertia was explained by spatial study $(2.3 \%)$, period $(2.3 \%)$ 199 and vegetation (14.4\%). Both vegetation and period represent $24.3 \%$ of total inertia (Figure 2). 200 Meiofauna abundance (ANOVA, $\mathrm{p}<0.05$ ) and biomass (ANOVA, $\mathrm{p}<0.05$ ) were significantly different in the five mangrove stands. As expected, nematodes (70-94\%) and copepods (3-8\%) were the most abundant taxa, with 500-1,500 ind.10 $\mathrm{cm}^{-2}$ and 50-100 ind.10 $\mathrm{cm}^{-2}$, respectively. Bianchelli et al. (2010) and Pusceddu et al. (2011) have used the term "rare meiofauna taxa" for taxa representing $<1 \%$ of the total meiofauna abundance. Thus, seven groups belong to this category "rare taxa" in the effluent-receiving mangrove: turbellarians, tardigrada, kinorhyncha, halacaroidea, gastropoda, bivalvia and amphipoda whereas pygnogonida has been found twice in one sample out of five.

207 Meiofauna abundance decreased from the land side to the sea side of the mangrove, the minimum 208 being in the "S" salt flat with 427 ind.10 $\mathrm{cm}^{-2}$, and the maximum in the "ER" seaward Rhizophora 209 stand, with more than 1,420 ind $10 \mathrm{~cm}^{-2}$. The grey mangroves $A$. marina, "A", the mixed grey and stilt 210 mangrove, "MAR", and the inner R.stylosa, "CR", stands showed an abundance around 750 ind.10 $211 \mathrm{~cm}^{-2}$. Total meiofauna biomass exhibited similar spatial patterns as abundance. 

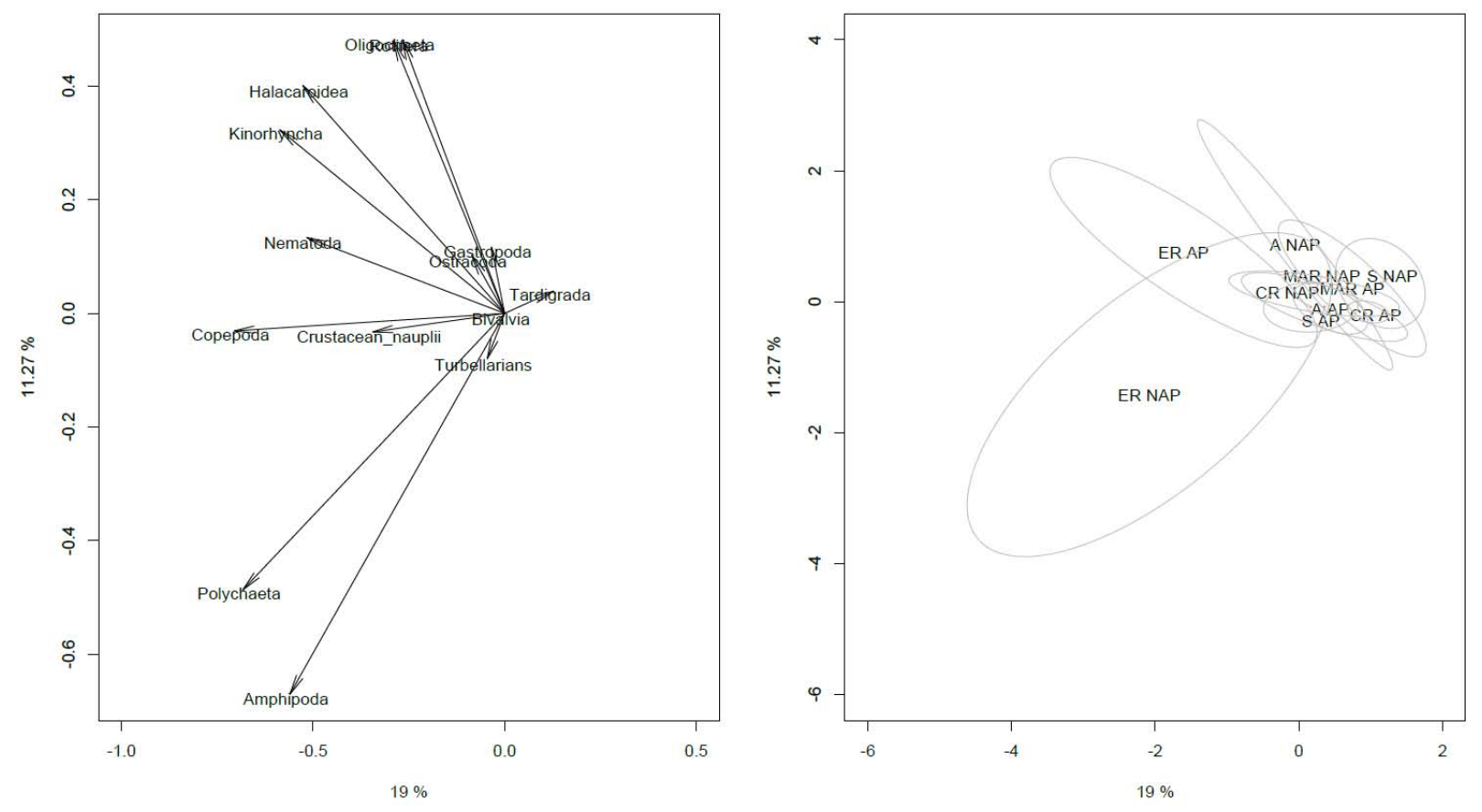

214 Figure 2 Principal Components Analysis (PCA) of the dual-season spatial study in effluentreceiving mangrove stands using meiofauna biomass. Left panel: loadings representing the extent to which the varaibles are correlated to principal components. Right panel: component scores.

\subsubsection{Distribution of the most abundant taxa: nematodes and copepods}

Nematode and copepod abundance (ANOVA, p Nem<0.05; p Cop $=0.05$ ) and biomass (ANOVA, p Nem<0.05; p Cop=0.05) were significantly different in the five mangrove stands $(\mathrm{p}<0.05)$. Their abundance slightly increased towards the sea, i.e. from "S" to "ER".

223 Nematoda represented the largest biomass (37-74\%) of meiofauna present in all the mangrove stands.

224 With exception of $47 \%$ in salt flat "S" during AP, the proportion of copepods in terms of biomass was 225 about $30 \%$ in all the mangrove stands. Relative biomass contribution of polychaeta (third biomass 226 contributor) increased towards the sea, and was very significant in the outer stilt mangrove "ER" (17$22723 \%$ ). Individual mass of nematodes also showed a remarkably progressive increase towards the sea side, with individual mass increasing fourfold, from 0.5 to $2 \mu \mathrm{g}$ (Figure 3). Copepod individual mass followed a different pattern. Individual mass around $3 \mu \mathrm{g}$ was observed in $4 / 5$ vegetation types: salt 
230 flat, grey mangrove, mixed grey and stilt mangroves, and seaward stilt mangrove, whereas smaller
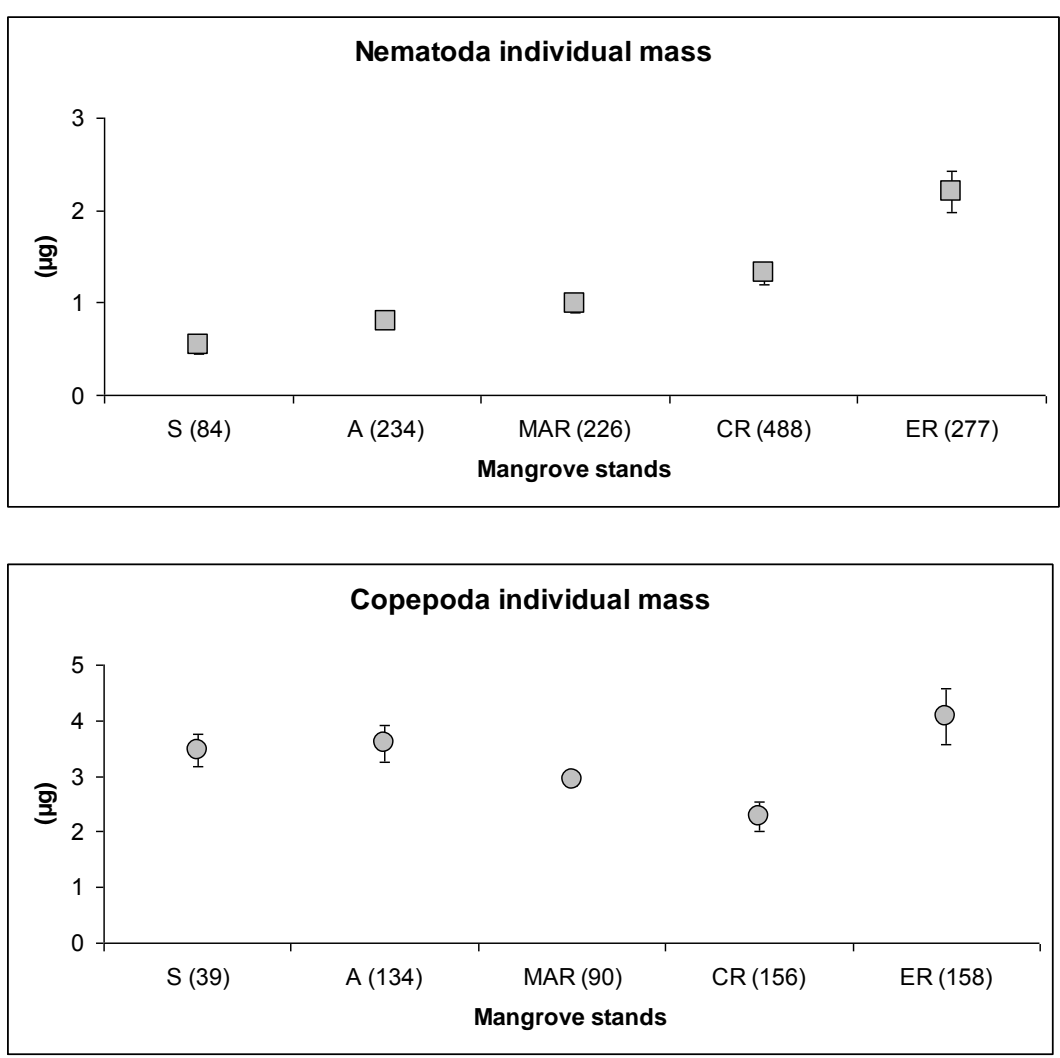

\subsubsection{Distribution of rare taxa} active period, respectively, and 0.3 ind $.10 \mathrm{~cm}^{-2}$ in A during the active period.

Figure 3 Individual mass $(\mu \mathrm{g})$ of nematodes and copepods in the different stands of the effluentreceiving mangrove (mean \pm S.D). "S" salt-marsh, "A" A.marina, "MAR" mixed zone harboring A. marina and Rhizophora stylosa, "CR" central zone with $R$. stylosa and "ER" seaward edge with $R$. stylosa. (average \pm SD); N (numbers of weighted specimens)

Turbellarians have been found in ER in three samples out of five during AP. Tardigrada (relative abundance $=0.79 \pm \mathrm{SD} 7.13 \%$ ) seemed to be restricted to less flooded sediments i.e S and to a lesser extent A sediments. They reached 53.2 and 0.7 ind. $10 \mathrm{~cm}^{-2}$ in $\mathrm{S}$ during non active period and

Amphipoda $(0.00 \pm \mathrm{SD} 0.03 \%)$ and bivalvia $(0.06 \pm \mathrm{SD} 0.21 \%)$ rarely exceeded 1.0 ind.10 $\mathrm{cm}^{-2}$ and have been found more abundant in sediments that are most often flooded (CR and ER). Halacaroidea 
(mites) $(0.06 \pm \mathrm{SD} 0.13 \%)$ and gastropoda $(0.04 \pm \mathrm{SD} 0.40 \%)$ were ubiquitously collected in five

1

stands in very low abundance $<3$ ind $.10 \mathrm{~cm}^{-2}$ whatever the period. In addition, anecdotal finding of one pygnogonida has been done once in ER in one sample out of five during NAP. Kinorhynchs represented only $0.16 \pm \mathrm{SD} 0.52 \%$ of the total meiofauna abundance. Kinorhynch abundance and biomass were significantly different in the five mangrove stands (Kruskal-Wallis, $p<0.05$ ) with lowest abundances in S, A, MAR, CR and highest in ER. They displayed their highest biomass in "ER" in both spatial studies (van der Waerden test; Chisq $=41.83$; p.chisq=3.52e-06) (Figure 4). Same results were obtained with their abundance (not shown). Mites abundance and biomass were significantly different in the five mangrove stands $(\mathrm{p}<0.05)$ with lowest abundances in $\mathrm{S}, \mathrm{A}, \mathrm{MAR}, \mathrm{CR}$ and highest in ER (van der Waerden test; Chisq $=17.56$; .chisq $=0.0015$ ).

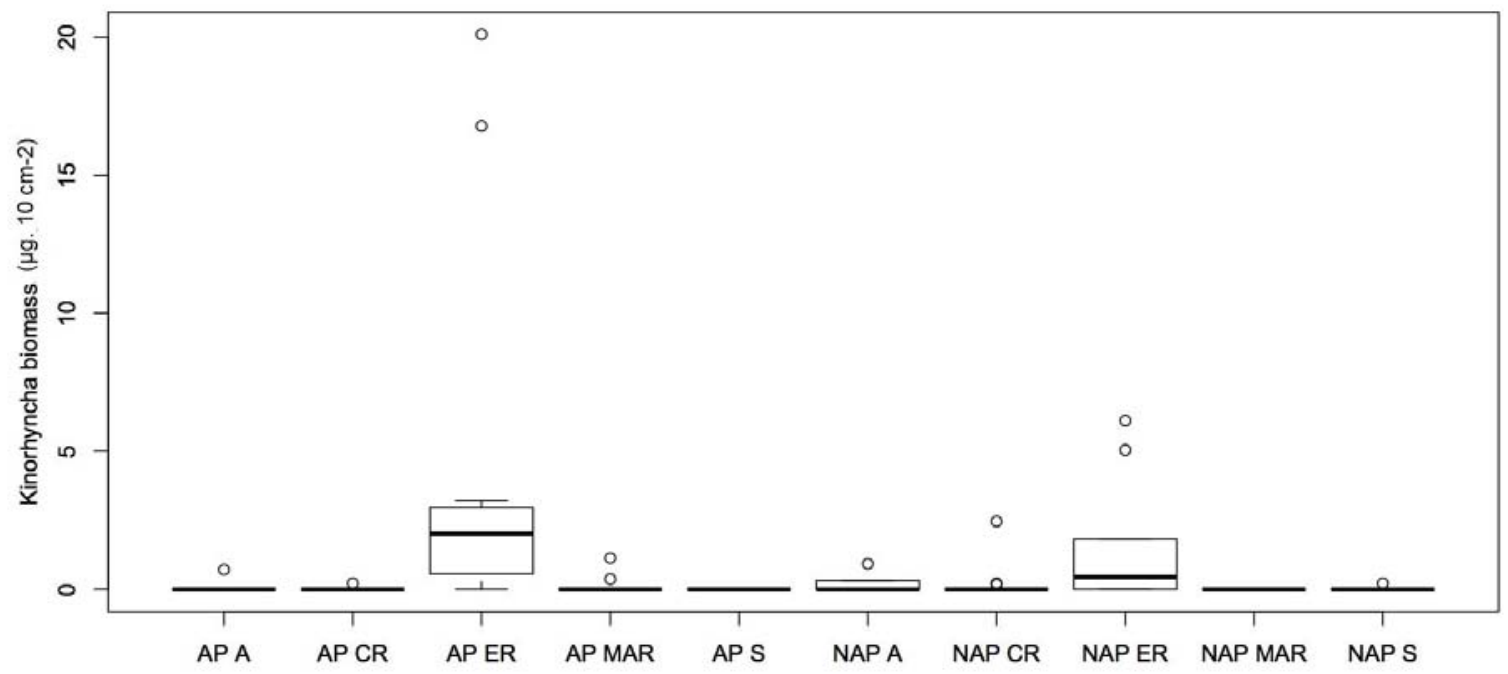

Figure 4 Importance of kinorhynchs biomass $\left(\mu \mathrm{g} 10 \mathrm{~cm}^{-2}\right)$ in different mangrove stands in both spatial studies according van der Waerden test. vdW test identified 3 groups. AP-ER belongs to 1st group; NAP-ER belongs to 2 nd group while other pairwises farm "activity-stand" belong to $3^{\text {rd }}$ and/or both two different groups. "S" salt-marsh, "A" A.marina, "MAR" mixed zone harboring A. marina and Rhizophora stylosa, "CR" central zone with $R$. stylosa and "ER" seaward edge with $R$. stylosa. "AP" Active Period. "NAP" Non active period. 


\section{the effluent-receiving mangrove (NAP vs. AP)}

\subsubsection{Total meiofauna abundance}

Abundance of total meiofauna was not significantly different $(p>0.05)$ before $(1033 \pm$ SD 86 ind. $10 \mathrm{~cm}^{-2}$ ) and after (921 \pm SD 129 ind. $10 \mathrm{~cm}^{-2}$ ) farm activity (NAP vs. AP) in the whole mangrove $(p>0.05)$ or in each stand separately $(p>0.05)$. Among thirteen meiofauna groups determined during the two sampling seasons, ten, including the two major groups nematodes and copepods, showed similar abundance and similar distribution in the different mangrove stands over the two spatial studies. In addition, during the AP, the abundance of crustacean nauplii and ostracods was up to 8 times higher compared to the NAP in the stand the closest to the ponds: the salt-flat "S" and the grey mangrove " $\mathrm{A}$ ".

\subsubsection{Total meiofauna biomass}

Biomass of total meiofauna was significantly different before $\left(635 \pm \mathrm{SD} \mu \mathrm{g} 10 \mathrm{~cm}^{2}\right)$ and after $\left(383 \pm \mathrm{SD} 40 \mu \mathrm{g} 10 \mathrm{~cm}^{2}\right)$ farm activity (norma.residu.p.value $=0.84$; bartlett.p.value $\left.=0.19\right)$ in effluent-receiving mangrove (Stand: F.value =12.04; Pr..F.=9.46e-08; Spatial study: F.value = 15.96; Pr..F. $=1.40 \mathrm{e}-04)$. During the NAP, meiobenthic biomass was up to 2 times higher compared to the AP in the CR (Tukey.p.value $=3.06 \mathrm{e}-02)$ and MAR $(\mathrm{p}=8.49 \mathrm{e}-02 ; \mathrm{n} . \mathrm{s})$. Significant larger specimens of nematodes, copepods and polychaetes $(\mathrm{p}<0.05)$ were observed in "MAR", "CR" and "ER" during non285 active period NAP of shrimp farm waste release, partially explaining total meiofauna biomass 286 difference (Figure 5). 


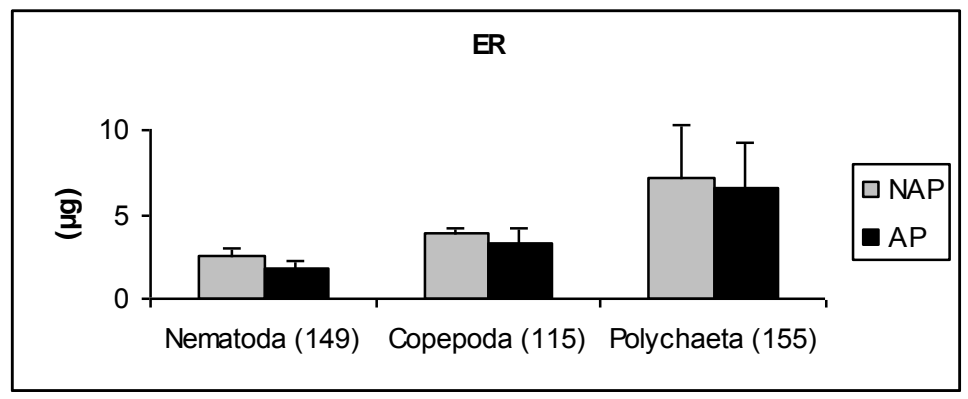

Figure 5 Individual mass $(\mu \mathrm{g})$ of nematodes, copepods and polychetes in "MAR" mixed zone harboring A. marina and Rhizophora stylosa, "CR" central zone with $\boldsymbol{R}$. stylosa and "ER" seaward edge with $\boldsymbol{R}$. stylosa recorded during active period AP and non-active period NAP of shrimp farm waste release. (average $\pm \mathrm{SD}$ ); $\mathrm{N}$ (numbers of weighted specimens).

\subsubsection{Rare taxa}

There were three times more kinorhynchs in "ER" during the AP (Kruskal-Wallis for Spatial study/Vegetation, $\mathrm{p}<0.05$ ). The abundance of waterbears (tardigrada) in " $S$ " was 50 times higher during the NAP $(\mathrm{p}<0.05)$. Turbellarians, halacaroidea, gastropoda, bivalvia and amphipoda did not showed significant differences in their abundance during AP and NAP. Pygnogonida were found in "ER" only during the NAP. 


\subsection{One-year monitoring in effluent-receiving and controlled $A$. marina stand}

\subsubsection{Meiofauna}

\subsubsection{Total meiofauna abundance in both control and effluent-receiving}

\section{A. marina stands}

On average, mean total meiofauna abundance in the effluent-receiving mangrove stand (305.3 \pm S.D 38.3 ind $\left..10 \mathrm{~cm}^{-2}\right)$ was twice the control mangrove stand $\left(165.2 \pm\right.$ S.E 29.1 ind.10 $\left.\mathrm{cm}^{-2}\right)$, $(\mathrm{p}<0.05)$. With regard to meiofauna abundance, PCA "inter" inertia was explained by environmental status $(3.7 \%)$ and campaign dates $(15.2 \%)$. Both status and dates represent $30.2 \%$ of total inertia. In the sediment of the control A. marina stand, total meiofauna abundance values were fairly stable from February to June 2009, with an average value around 50 ind.10 $\mathrm{cm}^{2}$, without any significant differences during the 4 sampling campaigns (Wilcoxon Test, $\mathrm{p}>0.05$ ). Then, abundance increased sharply until September, reaching a maximum of $439.2 \pm$ SD 219.2 ind.10 $\mathrm{cm}^{-2}$. From September 2009 to November 2009, it decreased quickly and stabilized at values around 125 ind.10 $\mathrm{cm}^{-2}$ (24 November 2009 to 8 February 2010). In the sediment of the effluent-receiving mangrove, when the farm was active, total meiofauna abundance increased significantly from February (100.1 \pm SD 0.3 ind. $\left.10 \mathrm{~cm}^{-2}\right)$ to June 2009 (347.4 \pm SD 266.1 ind. $\left.10 \mathrm{~cm}^{-2}\right)$ and stabilized at around 325 ind.10 $\mathrm{cm}^{-2}$ from June to August $\left(312.9 \pm \mathrm{SD} 106.5\right.$ ind $\left..10 \mathrm{~cm}^{-2}\right)$. After the final drain (August), i.e during the non-active period, abundance increased again and reached a maximum in September (538.9 \pm SD 285.8 ind.10 $\mathrm{cm}^{-2}$ ). It then decreased sharply to stabilize at around 300 ind.10 $\mathrm{cm}^{-2}$ (24 November 2009 to 8 February 2010).

\subsubsection{Total meiofauna biomass in both control and effluent-receiving $A$.} marina stands

The difference was also significant with regard to biomass $(p<0.05)$. On average, effluentsreceiving A.marina sediments had a meiofaunal biomass twice as large as the control sediments with $211.2 \pm \mathrm{SD} 34.3$ and $118.5 \pm \mathrm{SD} 19.2 \mu \mathrm{g} .10 \mathrm{~cm}^{-2}$, respectively. In terms of biomass, PCA "inter" inertia was explained by environmental status $(3.0 \%)$ and campaign dates $(17.6 \%)$. Both status and dates represent $30.7 \%$ of total inertia (Figure 6). Total meiofauna biomass differed significantly in 
331 terms of Environmental status (F.value=15.75; Pr..F. 2.04e-04) and campaign date (F.value= 16.22;

$\operatorname{Pr} . \mathrm{F}=1.54 \mathrm{e}-11)$ in both control and effluent-receiving A.marina stands. In the control mangrove, the total biomass was low and stable from February to June 2009 without any significant differences during the 4 sampling campaigns (Wilcoxon Test, $\mathrm{p}>0.05$ ), with values around $35 \mu \mathrm{g} .10 \mathrm{~cm}^{-2}$. It then increased, peaking at $302.7 \pm \mathrm{SD} 91.0 \mu \mathrm{g} .10 \mathrm{~cm}^{-2}$ in September, and eventually decreased to $109.5 \pm$ SD $33.2 \mu \mathrm{g} .10 \mathrm{~cm}^{-2}$ in February 2010. In the sediment of the effluent-receiving mangrove, when the farm was active, total meiobenthic biomass values were fairly stable from February to June, with an average value around $90 \mu \mathrm{g} .10 \mathrm{~cm}^{-2}$, without any significant differences during the 4 sampling campaigns (Wilcoxon Test, $\mathrm{p}>0.05$ ). In August after the final drain, the biomass increased, reaching $282.4 \pm \mathrm{SD} 124.1 \mu \mathrm{g} .10 \mathrm{~cm}^{-2}$. During the non-active period of the farm, from August to February, total meiobenthic biomass increased, with a mean value of $300.6 \pm$ SD $219.9 \mu \mathrm{g} .10 \mathrm{~cm}^{-2}$ (Figure 9).

ANOSIM showed significant differences $(\mathrm{R}=0.4199, \mathrm{p}<0.05)$ between meiofauna biomass compositions in both control and exposed A. marina stands (factor "status") during the 8 sampling campaigns from February 2009 to February 2010 (factor "Date"). Similarity of percentage tests (SIMPER) of cumulative contributions of most influential species showed that composition is mainly driven by nematodes and copepods. Actually, copepods (62 and $64 \%$ of total biomass in effluentreceiving and control mangroves) and nematodes (36\% and 34\%, respectively) were the most influential groups in terms of biomass (SIMPER analysis) and contributed at least $75 \%$ to the difference between groups (cumulative dissimilarity contribution) i.e. 0.786 and 0.774 , respectively 350 for nematodes and copepods in effluents-receiving sediments, 0.768 and 0.772 for nematodes and 351 copepods in control sediments, and 0.797 and 0.787 for nematodes and copepods in both sediments 352 (Effluents-receiving vs. control same date). 

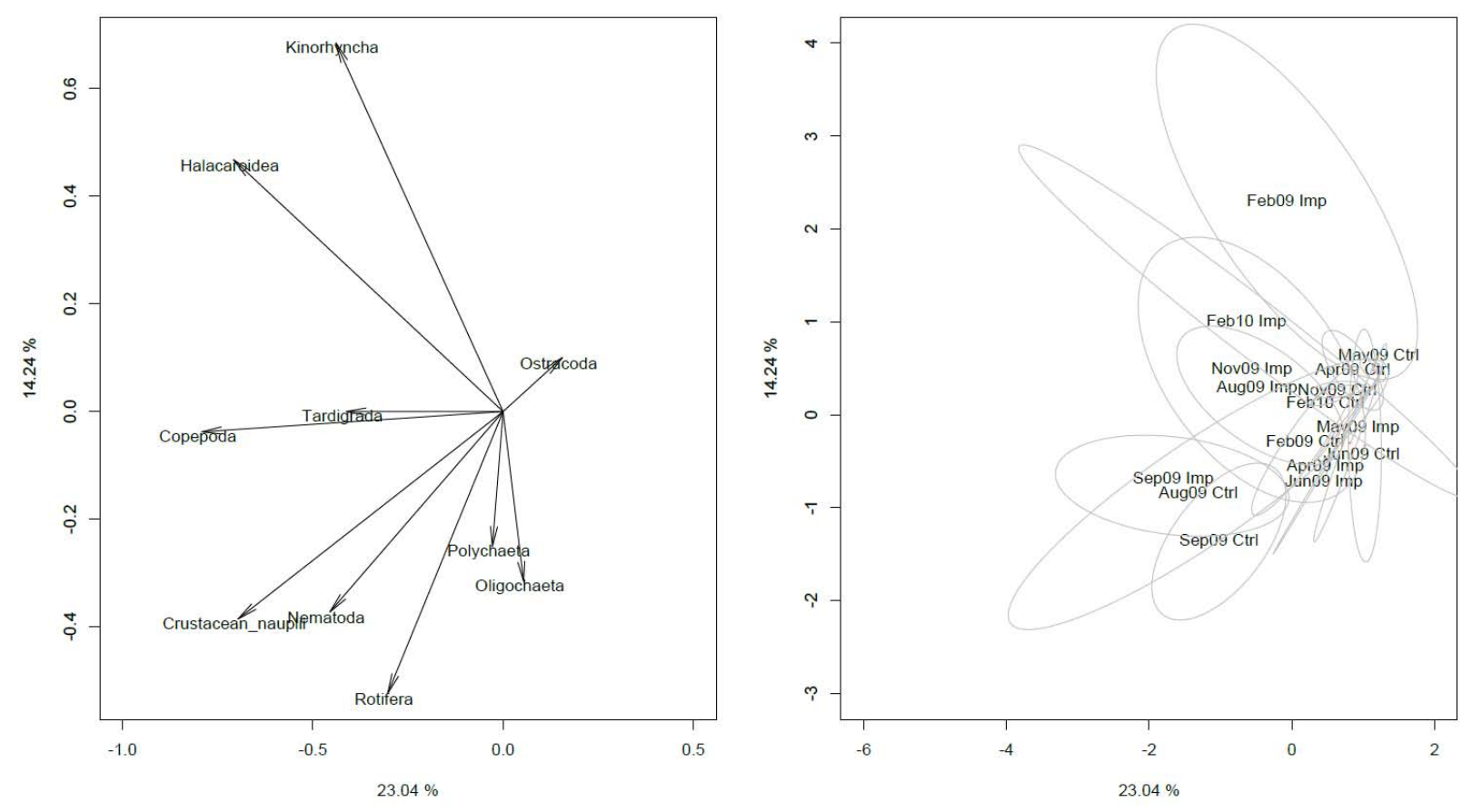

Figure 6 Principal Components Analysis (PCA) of the one-year monitoring in exposed and controlled $A$. marina stands using meiofauna biomass. Left panel loadings representing the extent to which the variables are correlated to principal components. Right panel: component scores.

3.2.1.3 Temporal changes of nematodes and copepods abundances and biomass in both control and effluent-receiving $A$. marina stands

The temporal variations of abundance of nematodes and copepods differed between the control and the effluent-receiving A. marina vegetation. During the year, nematode abundance varied

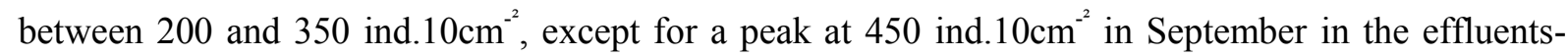
receiving sediments. In the control mangrove, nematodes abundance remained low from February to June $\left(<100\right.$ ind. $\left.10 \mathrm{~cm}^{-2}\right)$, and then increased to the same values as those measured in the effluentreceiving mangrove. From February to June, the abundance of copepods was low and stable with no more than 10 ind. $10 \mathrm{~cm}^{-2}$ in both sites. From July, a dramatic $900 \%$ increase occurred synchronously in both sites, with abundances reaching 100 ind. $10 \mathrm{~cm}^{-2}$ in August. However, after this increase, the 
abundance of copepods slightly decreased but remained high in the effluent-receiving mangrove (60 to

80 ind. $10 \mathrm{~cm}^{-2}$ ), whereas it gradually decreased to 25 ind. $10 \mathrm{~cm}^{-2}$ in the control site (Figure 7).
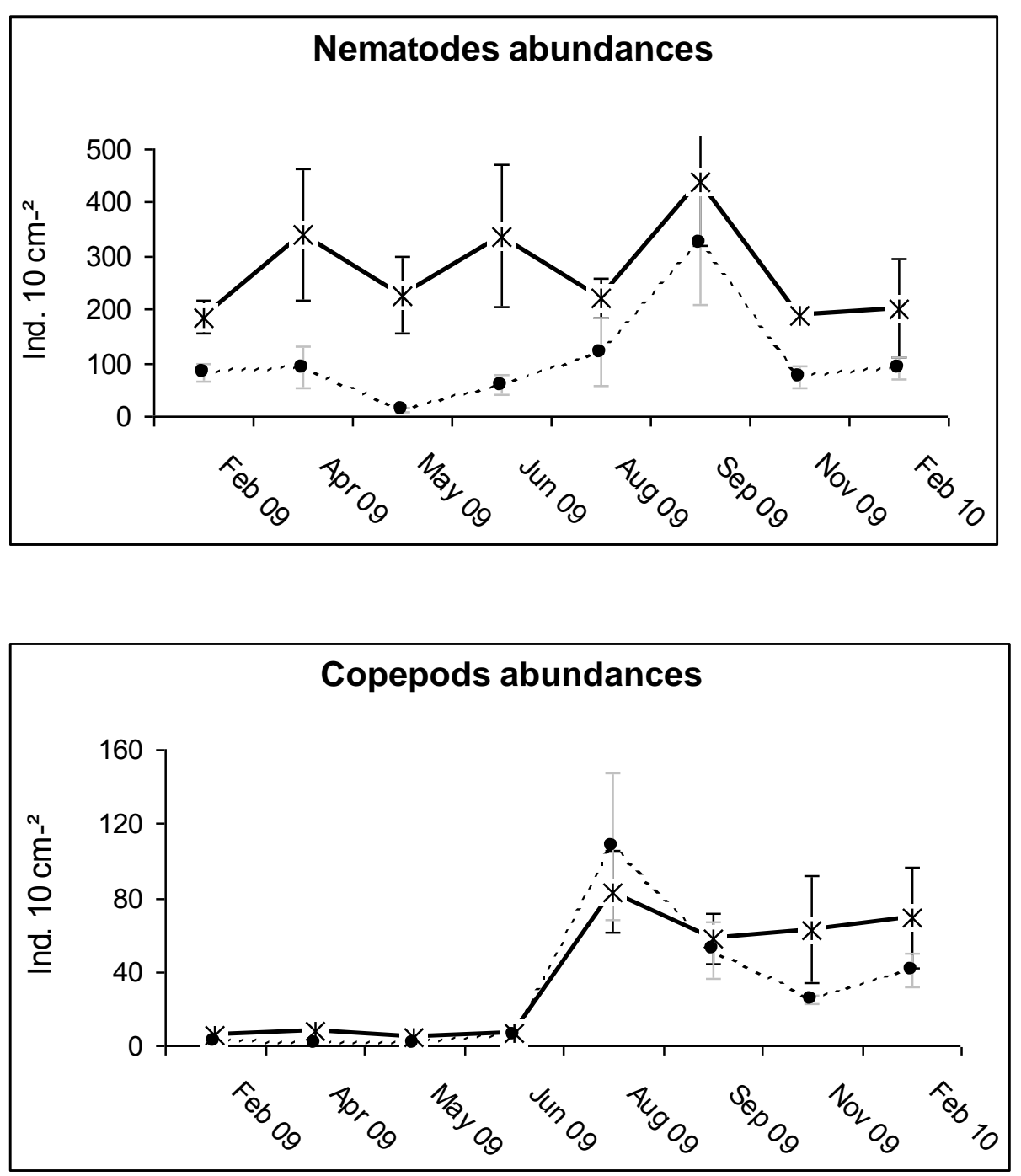

374 Figure 7 Nematoda abundance (above) and copepoda abundance (below) (ind. $10 \mathrm{~cm}^{-2}$ ) measured within sediment in the effluent-receiving mangrove and in the control mangrove during 8 campaigns between February 2009 and February 2010. The impact of effluents (February to June) barely registers on copepods while it is very noticeable on nematodes (Control sediment: dotted line with black circle; Effluents receiving sediment: solid line with stars; (average \pm SD) 
384 Three rare taxa were found in very low quantities in the sediments of effluent-receiving and control 385 vegetations. Turbellarians have been observed in February 2010 in the effluent-receiving A.marina 386 stand $\left(0.6 \pm \mathrm{SD} 1.4\right.$ ind.10 $\left.\mathrm{cm}^{-2}\right)$ and in September 2009 in the control A.marina stand $(0.4 \pm \mathrm{SD} 0.4$ 387 ind. $10 \mathrm{~cm}^{-2}$ ). Gastropoda have been found in February 2010 in the effluent-receiving A.marina stand $388\left(0.4 \pm \mathrm{SD} 0.5\right.$ ind. $\left.10 \mathrm{~cm}^{-2}\right)$ and in November 2009 in the control A.marina stand $(0.1 \pm \mathrm{SD} 0.3$ ind.10 $389 \mathrm{~cm}^{-2}$ ). Pygnogonida have been observed only in February 2010 in the effluent-receiving A.marina 390 stand $\left(4.3 \pm\right.$ SD 9.5 ind. $\left.10 \mathrm{~cm}^{-2}\right)$. Neither bivalves nor amphipods have been observed. Kinorhynchs 391 have been found only in the effluent receiving A.marina sediments during 2009 and 2010 hot seasons 392 i.e $0.3 \pm \mathrm{SD} 0.6$ ind. $10 \mathrm{~cm}^{-2}$ (Feb.2009); $0.1 \pm \mathrm{SD} 0.3$ ind.10 $\mathrm{cm}^{-2}$ (Nov.2009) and $0.1 \pm \mathrm{SD} 0.3 \mathrm{ind} .10$ $393 \mathrm{~cm}^{-2}$ (Feb.2010). Mites (halacoidea) and waterbears (tardigrada) have been found almost all year round 394 in both control and effluent-receiving A. marina mangroves (Figure 8). Seasonal patterns of their 395 abundance in receiving-effluents sediments mirrored those observed in the control mangrove. On 396 average over the year, waterbears abundances did not differ significantly in effluents receiving and 397 control A.marina sediments $(\mathrm{p}>0.05)$, whereas mites were significantly more abundant in control 398 sediments $(\mathrm{p}<0.05)$ 


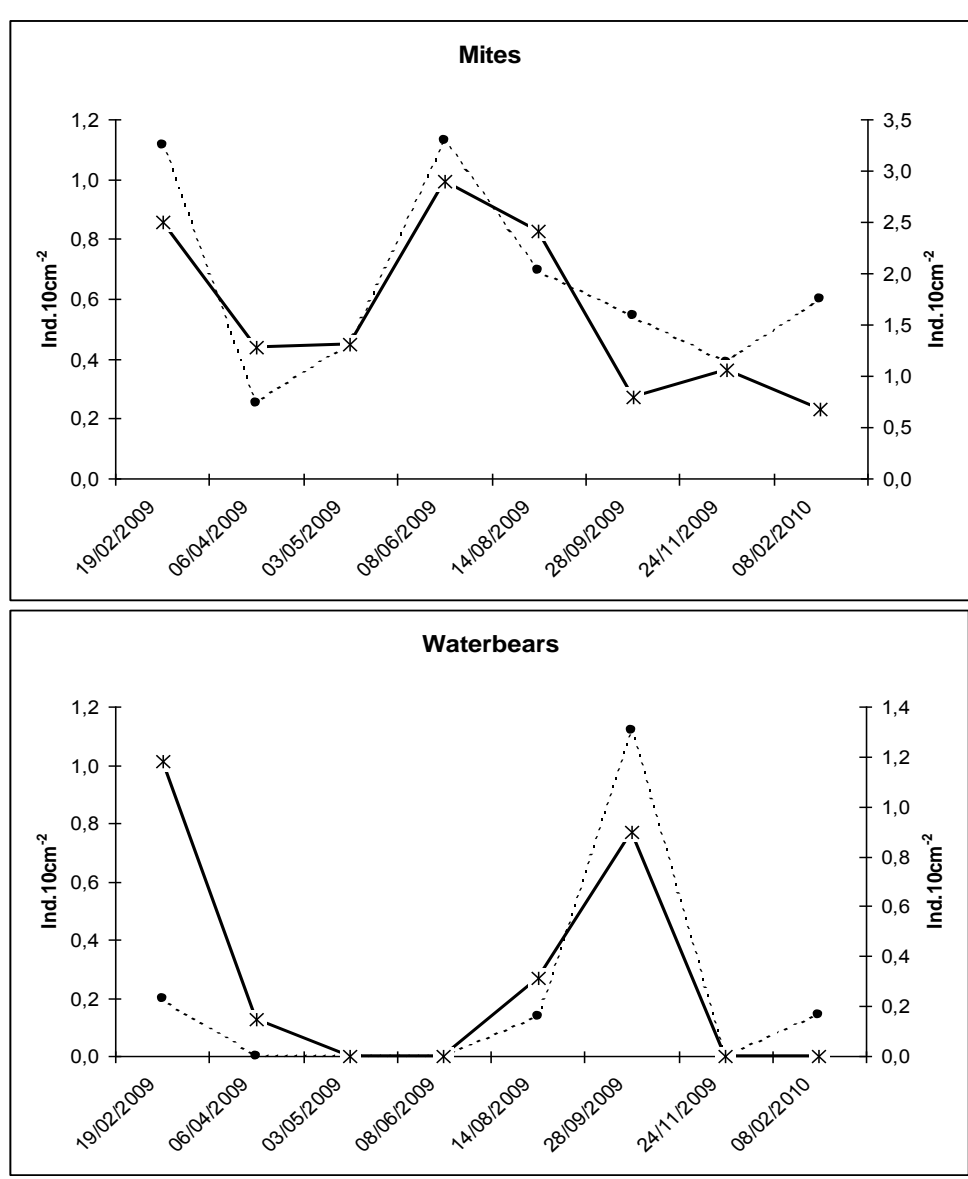

Figure 8 Rare taxa abundances (halacaroidea: mites, tardigrada: waterbears) (ind. $10 \mathrm{~cm}^{-2}$ ) measured within sediments in the effluent-receiving and in the control A.marina vegetations during 8 campaigns between February 2009 and February 2010 (Control sediments: dotted line with black circle; effluent-receiving sediments: solid line with stars).

\subsubsection{Microphytobenthos}

\subsubsection{Microphytobenthos temporal evolution}

Microphytobenthic Chl-a concentrations were significantly different between the two sites $409(\mathrm{p}<0.05)$. The surface sediment of the effluent-receiving Avicennia stand presented three times higher 410 Chl-a concentration than the control sediment, with on average $198.0 \pm$ SD $14.9 \mathrm{mgChl}-\mathrm{a} . \mathrm{m}^{-2}$ and 73.5 $411 \pm \mathrm{SD} 4.2 \mathrm{mgChl}-\mathrm{a} \cdot \mathrm{m}^{-2}$, respectively. From February to June, microphytobenthic Chl-a concentrations 412 were relatively stable in the control mangrove (Wilcoxon Test, $p>0.05$ ), while they increased and 413 peaked in September and decreased to February. The seasonal change of microphytobenthic Chl-a 414 concentrations in the effluent-receiving mangrove was different to that in the control mangrove. From 
415 February to June, when the farm was active, concentrations ranged between $119.3 \pm$ SD 60.3 and

1

$110.2 \pm$ SD $54.4 \mathrm{mgChl}-\mathrm{a} . \mathrm{m}^{-2}$, without any significant differences during the 4 sampling campaigns (Wilcoxon Test, $\mathrm{p}>0.05$ ). In August after the final drain, the concentrations increased, reaching 217.2 \pm SD $92.7 \mathrm{mgChl}-\mathrm{a} \cdot \mathrm{m}^{-2}$. During the non-active period of the farm, from August to February, microphytobenthic Chl-a concentrations increased, with a mean value of $269.0 \pm$ SD $113.5 \mathrm{mgChl}-$ a. $m^{-2}$ (Figure 9).
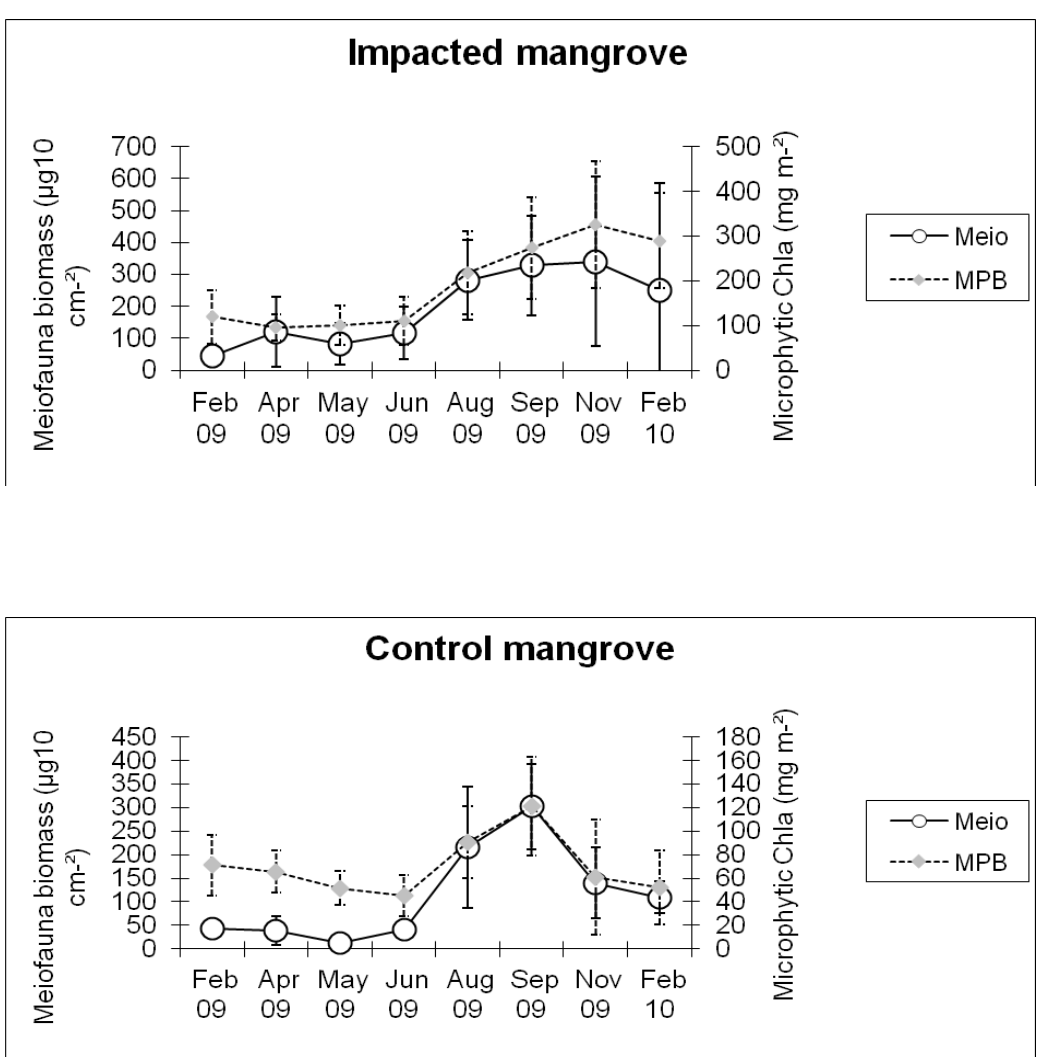

Figure 9 Temporal variations in total meiofauna biomass $\left(\mu \mathrm{g} 10 \mathrm{~cm}^{-2}\right)$ and microphytobenthic $425 \mathrm{Chl-a}\left(\mathrm{mg} \mathrm{m}^{-2}\right)($ average $\pm \mathrm{SD})$ in control mangrove and effluent receiving mangrove. Seasonal 426 patterns in meiofaunal biomass mirror the patterns of microphytobenthic Chl-a.

\subsubsection{Parallel microphytobenthos and meiofauna temporal evolution}

429 Pearson product-moment correlation coefficient indicated that meiofauna and microphytobenthos 430 biomass were positively correlated and followed very similar patterns at both sites (control $t=4.2159$, $431 \mathrm{df}=6, \mathrm{p}$-value $=0.005586, \mathrm{r}=0.8646534 ;$ impacted $\mathrm{t}=5.9269, \mathrm{df}=6, \mathrm{p}$-value $=0.001028, \mathrm{r}=$ 4320.9241838 ) during the same period. 


\section{Discussion}

4.1. General characteristics of meiofauna distribution in the whole mangrove area receiving shrimp farm effluents

In the whole mangrove area that has received shrimp farm effluents over a period of 25 years, meiofauna abundance ranged between 70 and 5,137 ind $10 \mathrm{~cm}^{-2}$, which is similar to natural mangrove sediments worldwide (Coull, 1999). The top three contributors to biomass identified in the effluentreceiving mangrove were nematodes $(57.3 \%)$, copepods $(31.3 \%)$ and annelids $(6.3 \%)$ confirming that such taxa are the most ubiquitous taxa in mangroves, as observed in Brazil (Netto and Galluci, 2003), in Vietnam (Xuan et al., 2007; Mokievsky et al. 2011), and in India (Chinnadurai and Fernando, 2006; Chinnadurai and Fernando, 2007; Thilagavathi et al., 2011). Consequently, we suggest that 25 years of release of aquaculture effluents into the mangrove has not caused any severe changes in benthic meiofauna in terms of total abundance or biomass. This conclusion is in agreement with that of Molnar et al. (2014), who did not find any signs of saturation, eutrophication or anoxia of the sediment of the same effluents receiving mangrove.

\subsection{Meiofauna distribution in the whole mangrove in relation to mangrove stand and} farm activity

4.2.1. Meiofaunal distribution in the whole mangrove during the non-active period: the influence of mangrove zonation.

Meiofauna abundance and biomass increased from the land side to the sea side of the mangrove, i.e. from the closest to the furthest point of the effluent discharge. At first glance, this result may suggest a situation of hyper-eutrophication (Environment Canada, 2010). Nevertheless, individual mass and consequently total biomass did not show any specific changes in relation to the distance from the discharge point. In New Caledonia, from the salt flat to the Rhizophora stand, the physicchemical parameters of the sediment present different gradients, notable salinity, water content, and organic matter (Deborde et al., 2015). We thus suggest the abundance and biomass increases towards the sea was rather related to the decreasing salinity of pore waters from the land side to the sea side of 
461 the mangrove (Molnar et al., 2014), salinity being recognized as a key parameter of meiofauna

distribution. In mangrove ecosystems, salinity is mainly driven by the length of tidal immersion and thus by the elevation of the soil, and thus increases towards the land. The salinity gradient is also responsible for the mangrove species distribution along the tidal zone, the ability of mangrove trees to cope with high salinity differs among species (Marchand et al., 2011). Actually, in New Caledonia, pore-water salinity in salt flats can reach more than $80 \%$ (Marchand et al., 2011), and sediment temperature can be as high as $43^{\circ} \mathrm{C}$ or more, inducing high evaporation (Leopold et al., 2015). Meiofauna biomass and abundance differed between vegetation, but some differences were also observed within sediments of the same mangrove species. The fringing $R$. stylosa presented higher abundance and biomass than the inner Rhizophora stand. In fact, Rhizophora trees, growing at the edge of the sea, present higher abundance and more developed root system than inland, and this can create a favorable environment for the development of numerous taxa. Furthermore, this particular sediment consists of a coarser grain size linked to the high energy of the sea side zone, as well as a lower organic content of the sediment linked to tidal flushing (Marchand et al., 2004), which may induced better sediment oxygenation than in the inner Rhizophora zone, which is known to be strongly anoxic (Deborde et al., 2015). With regard to the Avicennia stand, which is situated between the salt flat and the Rhizophora stand, its sediments have high biomass and the highest abundance of meiofauna. In addition to sediment grain size and food availability, Avicennia pneumatophores probably act as a more effective barrier than the Rhizophora stilts for meiofauna (Chinnadurai and 480 Fernando (2007). Furthermore, Avicennia's specific root system, by diffusing oxygen into the 481 sediment (Marchand et al., 2004), may create more favorable conditions for meiofauna development. 482 Eventually, Avicennia sp. leaves, which have high nitrogen content and low $\mathrm{C} / \mathrm{N}$ ratios, decompose 483 faster (Robertson, 1988), and may be more easily accessible to meiofauna than Rhizophora leaves that 484 are rich in tannins, which by acidity and/or toxicity adversely affect meiofauna (Alongi, 1987c). 


\section{active and the non active periods.}

Over the course of the 8 month rearing cycle, the total $\mathrm{N}$ and $\mathrm{P}$ loads to the mangrove were approximately 2.3 and 0.5 tons of $\mathrm{N}$ and $\mathrm{P}$, respectively, which are equivalent to loads of $79 \mathrm{~kg} \mathrm{~N} \mathrm{ha}^{-1}$ and $19 \mathrm{~kg} \mathrm{P} \mathrm{ha}^{-1}$ (Molnar et al., 2013). Short-term effects of effluent release on total meiofaunal was expected, and thus samples were collected during the farm's active and non-active periods. At the whole mangrove scale, we did not observe any significant differences in terms of abundance but in terms of biomass between AP and NAP periods, which may seem paradoxical. It is known that intraspecific variation of animal size may be correlated with organic enrichment (Weston, 1990 ; Grall and Chauvaud, 2002). In fact, significant smaller specimens of nematodes, copepods and polychaetes were found during the active period. In the present study, releasing effluents into the mangrove led to a decrease in the length of sediment air exposure, a reduced availability of dissolved oxygen in pore waters, and thus to more hypoxic conditions (Molnar et al., 2014). One explanation would be that the transient combination of moderate organic enrichment and reduced availability of dissolved oxygen in pore waters during the AP may selectively promote the smaller species. Additionally, effluent release occurred during the cold season, when the metabolism of benthic organisms is at its minimum (Santos et al., 1996), and the final drain occurred just before the seasonal temperature increase, a period during which the microphytobenthos biomass increased in the control mangrove. The seasonal variations may be responsible for this difference in biomass. A reversal of the NAP (June) vs. AP (November) situation from the one studied in the present study would have been extremely informative to distinguish the respective influence of farm and seasons. However, owing to reduced profits, New Caledonian shrimp farmers no longer stock their ponds in the cold season (May-June) with a view to harvest in the hot season (November-December). Consequently, this sampling strategy cannot be developed in New Caledonia. Hence, we have carried out a parallel one-year monitoring of meiofauna distribution in the Avicennia stand, the closest vegetated stand to the ponds, both in the effluentreceiving mangrove and in a control stand. 
receiving the effluents.

\subsubsection{Response of specific taxa}

\subsubsection{Most abundant taxa: nematodes and copepods}

At the crop scale, the impact of effluents was not identifiable on copepods but was noticeable on nematodes in the Avicennia stand (Figure 7). Copepods abundance remained low throughout the farm's active period. Consequently, the massive arrival of water enriched in potential food sources did not stimulated copepods development. We suggest that main changes displayed by copepods populations are mainly related to their natural cycle (reproduction), as their blooms occurred simultaneously in the effluent-receiving and in the control mangroves characterized by significant different microphytobenthos biomass. Nematode populations displayed an opposite trend than that of copepods. Shrimp farm effluents seemed to highly stimulate their development, while they remained low in the control site over the period February to June 2009. Shrimp farm wastes contain highly diversified phytoplankton cells up to 20 millions cel. $\mathrm{ml}^{-1}$ (Della Patrona and Brun, 2009) that constitute a very important food source for epistrate feeders, that are known to directly assimilate it (Olafsson and Elmgren, 1997). We thus suggest that these phytoplankton-rich effluents directly and specifically enhance epistrate-feeder populations that are the dominant trophic nematofauna group in the A.marina stand (Chinnadurai and Fernando, 2007). Under the influence of anoxic conditions, the general pattern consists of an increase in "less sensitive" nematodes in conjunction with a decrease in "very sensitive" copepods (Vezzulli et al. 2003; Moreno et al., 2008). However, the semi-intensive rearing system of New Caledonia did not led to such severe conditions and did not disrupt copepods life cycle as reported in sediments subjected to mussel farm biodeposition (Danovaro et al., 2004) or to some peculiar well managed fish farms (Holmer et al., 2008; Mirto et al., 2010).

\subsubsection{Rare taxa}

The large dominance of nematodes, copepods and polychaetes can mask the presence or the evolution of other taxa (Bianchelli et al., 2010; Pusceddu et al., 2011). Some rare taxa are recognized as providing more reliable and clear results on the degree of eutrophication than ubiquitous groups 
541 (Mirto et al., 2010; Gambi et al., 2010. In this regard, kinorhynchs, is the most frequently rare taxon

examined in aquaculture studies (Mazzola et al., 1999; Mazzola et al., 2000; Nadjek et al., 2007; Holmer et al., 2008; Grego et al., 2009). In the present study, kinorhynchs populations displayed an opposite trend to what was expected. They were present in impacted sediments and absent in control ones. Actually, we assume that owing to its characteristics (low water and OM contents, high pore water salinity and elevated insolation), the sediment of the control site had probably insufficient trophic capacity for kinorhynchs development. Furthermore, this taxon was only observed during the hot season (November to February), confirming their elevated requirements. Mites, which are usually observed in intertidal environments (Marshall et al., 2001), may be very abundant in tropical estuaries (Nozais et al., 2005). In this study, mites abundance peaked during the cold season (June to August) while usually maximum abundance of meiofauna peaks in the warm months (Giere, 1993). However, individual taxa or species may reach maximum abundance at different periods (Higgins and Thiel, 1988) a fortiori in tropical conditions where differences in temperatures are less pronounced. As stated for tardigrades, seasonal shrimp farm activity (AP) did not disturb the natural cycle of mites in A.marina sediments. However, mites were found three times less abundant in the effluents-receiving A.marina stand than in the control one. Unlike kinorhynchs, mites were ubiquitously found in the different mangrove stands and almost all year round. Consequently, we suggest that this rare taxon may be a useful indicator of long term shrimp farm biodeposition in mangrove.

\subsubsection{Total meiofauna and microphytobenthos parallel changes}

\subsubsection{Response of microphytobenthos to shrimp farm effluents}

In addition to the meiofauna distribution, we were also interested in the Chl-a content of the surface sediment in the A.marina stand. Actually, along the mangrove zonation in New Caledonia, Leopold et al. (2013) showed that the A.marina stand, with its intermediate position in the tidal zone, was the preferential zone for the development of MPB, because i) the canopy cover was not dense and enabled solar radiation to reach the soil and ii) ideal soil water content, not immerged all the time and never dry. In the present study, the surface sediment of the effluent-receiving A.marina stand had a Chl-a concentration three times higher and a meiofaunal biomass, as well as a total abundance, twice 
569 as large as the control sediment, demonstrating the influence of shrimp farming on this mangrove.

However, Chl-a concentrations never exceeded a threshold above which, it is possible to consider an eutrophication of the ecosystem, which is consistent with previous results showing the light evolution of the effluent-receiving mangrove (Molnar et al., 2013; 2014; Debenay et al., 2015). Thus, microphytobenthos (MPB) biomass can be a good descriptor of shrimp farm effluents disturbance in mangrove.

\subsubsection{Complex interaction between meiofauna and microphytobenthos}

Seasonal patterns in meiofaunal biomass mirrored the patterns of microphytobenthic Chl-a highlighting a possible causal trophic relationship. Actually, most of meiofauna taxa are important consumers of microphytobenthos (Nozais et al., 2005). In open areas, contradictory results have been observed (Mirto et al., 2007). La Rosa et al. (2001) reported that meiofaunal and microphytobentic biomass increased synchronously in response to organic enrichment under fish cages. At the opposite, Vezzulli et al. (2003) reported that meiofauna abundance was not correlated to the microphytobenthos or that of bacteria. In our study site, Aschenbroich et al. (2015) have shown that mangrove benthic organic matter is qualitatively and quantitatively affected by shrimp farm effluent release and that responses to environmental condition changed depend on mangrove stand characteristics. Additionally, it was demonstrated that i) the OM exported from the ponds stimulated oxygen demand and nutrient regeneration rates in sediments of the closest mangrove stand, resulting in large effluxes of dissolved organic and inorganic nutrients into the overlying water, ii) benthic primary productivity at sediment surface was enhanced, even after the cessation of the release, iii) microalgal communities shifted (Aschenbroich et al., 2015; Molnar et al., 2013; 2014; Debenay et al., 2015). We thus suggest that qualitative and quantitative changes in MPB can directly influence meiofauna development in A.marina stand, however it is difficult to determine the respective influence of natural seasonal evolution and effluents on MPB development. In fact, trophic interaction between different benthic components as organic matter quality (carbohydrates, proteins, lipids, Chl-a contents), meiofauna, bacteria and protozoa are very complex (Danovaro et al., 2004; Vezzulli et al., 2003). 
This study suggests that abundance, biomass and individual mass of meiofauna taxa rather vary according mangrove zonation than under the influence of shrimp farm effluents. Meiofauna sealand gradients cannot be attributed to an eventual flume effect of shrimp farm wastes but rather to different biogeochemical properties of sediments induced by different mangrove roots systems and/or length of tidal immersion. The Rhizophora stand was characterized by the highest meiofauna biomass, however the stand with the largest ecological interest was the A.marina stand, which harbored both higher meiofaunal abundance and higher microphytobenthic biomass. We suggest that the meiofauna development was linked to the quantity and quality of the MPB, which were driven both by the release of effluents and the climatic seasonal evolution. The fact that the final drain of the shrimp ponds occurred just before the seasonal temperature increase induced a boosted algal bloom and meiofauna development. It is thus difficult to conclude on the influence on releasing shrimp farm effluents on meiofauna distribution in mangrove on a short term. However, the long-term (25 years) effect of effluents led to a situation where mangrove sediments presented higher meiofaunal abundance and biomass that the control one, and more interestingly, were characterized by additional taxonomic groups compared to the control site. Consequently, our results suggest that semi-intensive farming in the investigated system (FAO) has a low impact on the environnemental quality of the adjacent mangrove. However, it does not seem appropriate to extrapolate this result to all New Caledonian farms, because the amount of effluents released in the mangrove per area unit, and the way they are released may differ from one farm to another. Shrimp farming is one of the main cause of mangrove destruction worldwide, this study shows that other practices exist, and that mangrove and shrimpfarming can co-exist.

\section{Acknowledgments}

622 This work has been supported by the ZONECO Program. We thank the shrimp farming company 623 FAO, and Christophe Canel, which kindly made this study possible. The authors would like to thank the two anonymous reviewers, who made valuable suggestions for improving the manuscript. 


\section{References}

Alongi, D.M., 1987a. Inter-estuary variation and intertidal zonation of freeliving nematode communities in tropical mangrove systems.Marine Ecology Progress Series 40, 103-114.

Alongi, D.M., 1987b. Intertidal zonation and seasonality of meiobenthos in tropical mangrove estuaries. Marine Biology 95, 447-448.

Alongi, D.M., 1987c. The influence of mangrove-derived tannins on intertidal meiobenthos in tropical estuaries. Oecologia 71, 537-540.

Ansari, Z.A., Sreepada, R.A., Matondkar, S.G.P., Parulekar, A.H.,1993. Meiofauna stratification in relation to microbial food in a tropical mangrove mudflat.Tropical Ecology 34, 63-75.

Aschenbroich, A., Marchand, C., Molnar, N., Deborde, J., Hubas, C., Rybarczyk, H., Meziane, T., 2015. Spatio-temporal variations in the composition of organic matter in surface sediments of a mangrove receiving shrimp farm effluents (New Caledonia). Science of the Total Environment, 512, 296-307.

Bianchelli, S., Gambi, C., Zeppilli, D., Danovaro, R., 2010. Metazoan meiofauna in deep-sea canyons and adjacent open slopes: a large-scale comparison with focus on the rare taxa. Deep Sea Research I $57,420-433$.

649 Bianchelli, S., Pusceddu, A., Buschi, E., Danovaro, R., 2016. Trophic status and meiofauna 650 biodiversity in the Norther Adriatic Sea : Insights for the assessment of good environmental status.

Marine Environmental Research 113, 18-30. 
653 Bottrell, H.H., Duncan, A., Gliwicz, Z.M., Grygierck, E., Herzig, A., Hillbricht-Ilkowska, A., 1 2654 Kurusawa, H., Larsson, P., Wegelnska, T., 1976. A review of some problems in zooplankton 3

production studies. Norwegian Journal Zoology 24, 419-456.

Castel , J., Labourg, P.J., Escavarage, V., Auby, I., Garcia, M.E., 1989. Influence of seagrass beds and oysters park on the abundance and biomass patterns of meio-and macrobenthos in tidal flats. Estuarine, Coastal and Shelf Science 28, 71-85

Chinnadurai, G., Fernando, O.J., 2006. Meiobenthos of Cochin Mangroves (Southwest Coast of India) with emphasis on free living marine nematode assemblages. Russian Journal of Nematology 14, 127 137.

Chinnadurai, G., Fernando, O.J., 2007. Meiofauna of Mangroves of the Southeast Coast of India with special reference to the free-living marine nematode assemblage. Estuarine, Coastal and Shelf Science $72,329-336$

Coull, B.C, 1999. Role of meiofauna in estuarine soft bottoms Habitats. Australian Journal of Ecology $24,327-343$

Costanzo, S.D., O'Donohue, M.J., Dennison, W.C., 2004. Assessing the influence

and distribution of shrimp pond effluent in a tidal mangrove creek in North-East

Australia. Marine Pollution Bulletin 48, 514-525.

Danovaro, R., Gambi, R., Luna, G.M.,Mirto, S., 2004. Sustainable impact of mussel farming in the Adriatic Sea (Mediterranean Sea): evidence from biochemical, microbial and meiofaunal indicators. Marine Pollution Bulletin, 49, 325-333. 
Debenay, J.-P., Marchand, C., Molnar, N., Aschenbroich, A., Meziane, T., 2015. Foraminiferal

assemblages as bioindicators to assess potential pollution of mangroves acting as a natural biofilter for shrimp farm effluents (New Caledonia). Marine Pollution Bulletin 93, 103-120.

Deborde, J., Marchand, C., Molnar, N., Della Patrona, L., Meziane, T., 2015. Concentrations and fractionation of carbon, iron, sulfur, nitrogen and phosphorus in mangrove sediments along an intertidal gradient (semi-arid climate, New Caledonia). Journal of Marine Science and Engineering 3, $52-72$

Della Patrona, L., Brun, P., 2009. Elevage de la crevette bleue en Nouvelle-Calédonie Litopenaeus stylirostris Bases biologiques et zootechnie.LEAD/NC 320 p.7

Environnement Canada., 2010. Guide technique pour l'étude du suivi des effets sur l'environnement aquatique par les fabriques de pâtes et papiers. Aperçu du programme 2010. Environnement Canada, Bureau national des ESEE, Institut national de recherche sur les eaux, Gatineau (Québec), Canada.

Gambi, C., Lampadariou, N., Danovaro, R., 2010. Latitudinal, longitudinal and bathymetric patterns of abundance, biomass of metazoan meiofauna : importance of the rare taxa and anomalies in the deep Mediterranean Sea. Advances in Oceanography and Limnology 1, 167-198.

Giere, O., 1993. Meiobenthology. The microscopic fauna in Aquatic Sediments. Springer-Verlag. 
Gradinger, R., Friedrich, C., Spindler, M., 1999. Abundance, biomass and composition of the sea ice

biota of the Greenland Sea pack ice. Deep-Sea Research Part II Topical Studies in Oceanography 46, $1457-1472$.

Grall, J., Chauvaud, L., 2002. Marine eutrophication and benthos: the need for new approaches and concepts. Global Change Biology, 8, 813-830.

Grego, M., De Troch, M., Forte, J., Malej, A., 2009. Main meiofauna taxa as an indicator for assessing the spatial and seasonal impact of fish farming. Marine Pollution Bulletin 58, 1178-1186.

Guo, Y., Della Patrona, L., Reznik-Orignac, J., Boucher, G., 2005. La méiofaune des bassins à crevettes Litopenaeus stylirostris du syndrome d'hiver en Nouvelle-Calédonie. Rapport de contrat universitaire Ifremer/CNRS N²004 7523400. 20pp.

Higgins, R.P., Thiel, H., 1988. Introduction to the study of Meiofauna. Published by the Smisthsonian Institution Press. Washington,D.C.London.488p. Published by the Smisthsonian Institution Press. Washington,D.C.London. 488p.

Holmer, M., Frederiksen, M., Pusceddu, A., Danovaro, R., Mirto, S., Perez, M., Marbà, N., Duarte, C.M., Diaz-Almela, E., Tsapakis, M., Karakassis, Y. 2008. Effects of fish-farm waste on Posidonia oceanica meadows: synthesis and provision of management tools. Marine Pollution Bulletin 56, 16181629

Lacerda, L.D., 2006. Inputs of Nitrogen and Phosphorus to Estuaries of Northeastern Brazil from Intensive Shrimp Farming. Brazilian Journal of Aquatic Science and Technology 10,13-27.

Lamparadariou N., Karakassis, I., Terasche, S., Arlt, G., 2005. Changes in the benthic meiofaunal assemblages in the vicinity of fish farms in the eastern Mediterranean. Vie et Milieu 55, 61-69. 
La Rosa, T., Mirto, S., Mazzola, A., Danovaro, R., 2001. Differential responses of benthic microbes and meiofauna to fish-farm disturbance in coastal sediments. Environmental Pollution 112, 427-434.

Leopold, A., Marchand, C., Deborde, J., Chaduteau, C., Allenbach, M., 2013. Influence of mangrove zonation on CO 2 fluxes at the sediment-air interface (New Caledonia). Geoderma 202, 62-70.

Leopold, A., Marchand, C., Deborde, J., Allenbach, A., 2015. Temporal variability of CO2 fluxes at the sediment-air interface in mangroves (New Caledonia). Science of The Total Environment 502, $617-626$

McKinnon, A.D., Trott, L.A., Alongi, D.M., Davidson, A., 2002. Water column production and nutrient characteristics in mangrove creeks receiving shrimp farm effluent. Aquaculture Research $33,55-73$.

Marchand, C., Baltzer, F., Lallier-Vergès, E., Albéric, P., 2004. Pore water chemistry in mangrove sediments: relationship with species composition and developmental stages (French Guiana). Marine geology 208, 361-381.

Marchand, C., Lallier-Vergès, E., Allenbach, M., 2011. Redox conditions and heavy metals distribution in mangrove forests receiving effluents from shrimp farm effluents (Teremba bay, New Calodenia). J Soils and Sediments 11, 529-541

758 Marshall, D.J., Perissinotto, R., Nozais, C., Haines, C.J., Proche, S., 2001. Occurrenceof the 759 astigmatid mite Tyrophagusin estuarine benthic sediments. Journal of the Marine Biological 760 Association of the United Kingdom 81, 889-890. 
Mazzola, A., Mirto, S., Danovaro, R., 1999. Initial Fish-Farm impact on meiofaunal assemblages in

784

Mazzola, A., Mirto, S., La rosa, T., Fabiano, M., Danovaro, R., 2000. Fish-farming effects on benthic community structure in coastal sediments: analysis of meiofaunal recovery. ICES Journal of Marine Science 57, 1454-1461.

Mirto, S., Pusceddu, A., Gambi, C., Holmer, M., Danovaro, R., 2007. Ecological assessment of aquaculture impact in the Mediterranean Sea. Impact of mariculture on coastal ecosystems 32, 21-28. Workshop Monographs CIESM.

Mirto, S., Bianchelli, S., Gambi, C., Krzelj, M., Pusceddu, A., Scopa, M., Holmer, M., Danovaro, R., 2010. Fish-farm impact on metazoan meiofauna in the Mediterranean Sea : Analysis of regional vs. habitat effects. Marine Environmental Research 69, 38-47.

Mirto, S., Gristina, M., Sinopoli, M., Maricchiolo, G., Genovese, L., Vizzini, S., Mazzola, A., 2012. Meiofauna as an indicator for assessing the impact of fish farming at an exposed marine site. Ecological Indicators, 18, 468-476.

Mirto, S., Arigò, C., Genovese, L., Pusceddu, A., Gambi, C., Danovaro, R., 2014. Nematode assemblage response to fish-farm impact in vegetated (Posidonia oceanica) and non-vegetated habitats. Aquaculture Environment Interactions, 5, 17-28. zone in Nha Trang Bay (Vietnam) in the South China Sea. Russian Journal of Marine Biology 37, 272-283. 
Molnar, N., Welsh, D.T, Marchand, C., Deborde, J., Meziane, T., 2013. Impacts of shrimp farm

effluents on water quality, benthic metabolism and N-dynamics in a mangrove forest (New

Caledonia). Estuarine Coastal and Shelf Sciences 117, 12-21.

Molnar, N., Marchand, C., Deborde, J., Della Patrona, L., Meziane, T., 2014. Seasonal pattern of the biogeochemical properties of mangrove sediments receiving shrimp farm ef- fluents (New Caledonia). Jounal of Aquaculture Research and Development 5, 262-270.

Moreno, M., Vezzulli, L., Marin, V., Laconi, P., Albertelli, G., fabiano, M., 2008. The use of meiofauna diversity as an indicator of pollution in harbours. ICES Journal of Marine Science, 65: $1428-1435$.

Najdek, M., Travizi, A., Bogner, D., Blazina, M., 2007. Low impact of marine fish farming on sediment and meiofauna in Limski Channel (Northern Adriatic, Croatia). Fresenius Environmental Bulletin 16, 784-791.

Netto, S.A., Gallucci, F., 2003. Meiofauna and macrofauna communities in a mangrove from the island of Santa Catarina, South Brazil. Hydrobiologia 505, 159-170.

Nozais, C., Perissinotto, R., Tita, G., 2005. Seasonal dynamics of meiofauna in a South African Temporarily-open Estuary. Estuarine, Coastal and Shelf Sciences62, 325-338.

Olafsson, E., Elmgren, R., 1997. Seasonal dynamics of Sublittoral meiobenthos in relation to phytoplankton sedimentation in the Baltic Sea. Estuarine, Coastal and Shelf Science 45, 149-164.

815 Olafsson, E., Johnston, R.W., Ndaro, S.G.M., 1995. Effects of intensive seaweed farming on the meiobenthos in a tropical lagoon. Journal of Experimental Marine Biology and Ecology 191, 101-117. 
818 Pusceddu, A., Dell'Anno, A., Fabiano, M., Danovaro, R. 2008. Quantity, biochemical composition

and bioavailability of sediment organic matter as complementary signatures of benthic trophic status.

Marine Ecology Progress Series, 375, 41-52

Pusceddu, A., Bianchelli, S., Gambi, C., Danovaro, R., 2011. Assessment of benthic trophic status of marine coastal ecosystems: significance of meiofaunal rare taxa. Estuarine, Coastal and Shelf Science 93, 420-430.

Santos, P., Castel, J.P., Souza-Santos, L.P., 1996. Seasonal variability of meiofaunal abundance in the oligo-mesohaline area of the Gironde Estuary, France. Estuarine, Coastal and Shelf Science 43, 549837563.

Thilagavathi, B., Das, B., Saravanakumar, A., Raja, K., 2011. Benthic meiofaunal composition and

843 Thomas, Y., Courties, C., El Helwe, Y., Herbland, A., Lemonnier, H., 2010. Spatial and temporal 844 extension of eutrophication associated with shrimp farm wastewater discharges in the New Caledonia 845 lagoon. Marine Pollution Bulletin 61, 387-398. 
Vanhove, S., Vincx, M., Gansbeke, D.V., Gijselinck, W., Schram,D., 1992. The miobenthos of five mangrove vegetation types in Gazi Bay, Kenya. Hydrobiologia, 247, 99-108.

Vezzulli, L., Marrale., D., Moreno, M.P., Fabiano, M., 2003. Sediment organic matter and meiofauna community response to long-term fish farm impact in the Ligurian Sea (Western Mediterranean). Chemistry and Ecology 19, 431-440.

Vezzulli, L., Moreno, M., Marin, V., Pezzati, E., Bartoli, M., Fabiano, M., 2008. Organic waste impact of capture-based Atlantic Bluefin Tuna aquaculture at an exposed site in the Mediterranean Sea. Estuarine, Coastal and Shelf Science 78, 369-384.

Warwick, R.M., Price, R., 1979. Ecological and metabolic studies on free living Nematodes from an estuarine mud flat. Estuarine, Coastal and Shelf Science 9, 257-271.

Warwick, R.M., Gee, J.M., 1984. Community structure of estuarine Meiobenthos. Marine Ecology Progress Series18, 97-111.

Weston, D.P., 1990. Quantitative examination of macrobenthic community changes along an organic enrichment gradient. Marine Ecology Progress Series 61, 233-244.

867 Wieser, W., 1960. Benthic studies in Buzzards Bay.II. The meiofauna. Limnology and Oceanography $8685,121-137$

870 Xuan, Q.N., Vanreusel, A., Thanh, N.V., Smol, N., 2007. Biodiversity of Meiofauna in the Intertidal 871 Khe Nhan Mudflat, Can Gio Mangrove Forest, Vietnam with special emphasis on free living 872 nematodes. Ocean Science Journal 42, 135-152. 
874 Yentsch, C.S., Menzel, D.W., 1963. A method for the determination of phytoplankton chlorophyll and 1 2875 phaeophytin by fluorescence. Deep-Sea Research 10, 221-231.

3

4876

5

$\begin{array}{ll}6 & 877\end{array}$

8
9 878

10

11

12

13

14

15

16

17

18

19

20

21

22

23

24

25

26

27

28

29

30

31

32

33

34

35

36

37

38

39

40

41

42

43

44

45

46

47

48

49

50

51

52

53

54

55

56

57

58

59

60

61

62

63

64

65 